\title{
PENGARUH KECERDASAN EMOSIONAL, KOMPETENSI DAN KOMPENSASI FINANSIAL TERHADAP KINERJA KARYAWAN PT AGRANET MULTICITRA SIBERKOM (DETIKCOM)
}

\author{
Siti Nurhasanah \\ Rebin Sumardi \\ Email: sitinurhasanah1314@gmail.com, rebin_67@yahoo.com \\ Program Studi Manajemen Fakultas Ekonomi \\ Universitas Nasional
}

\begin{abstract}
ABSTRAK
Penelitian ini bertujuan untuk menguji dan menganalisis pengaruh kecerdasan emosional, kompetensi dan kompensasi finansial terhadap kinerja karyawan PT Agranet Multicitra Siberkom (Detikcom). Data penelitian ini merupakan data primer dari penyebaran kuesioner kepada 80 karyawan PT Agranet Multicitra Siberkom (Detikcom). Penelitian menggunakan metode analisis regresi linier berganda. Hasil penelitian menunjukkan bahwa kecerdasan emosional, kompetensi dan kompensasi finansial secara parsial berpengaruh positif dan signifikan terhadap kinerja karyawan PT Agranet Multicitra Siberkom (Detikcom).
\end{abstract}

Kata kunci: Kecerdasan emosional, kompetensi, kompensasi financial, kinerja karyawan

\section{ABSTRACT}

This study aims to examine and analyze the effect of emotional intelligence, competence and financial compensation on employee performance of PT Agranet Multicitra Siberkom (Detikcom). Data of this study was primary data from questionnaires distribution to 80 employees of PT Agranet Multicitra Siberkom (Detikcom). The sudy used multiple linear regression analysis method. Results of the study showed that emotional intelligence, competence and financial compensation partially has positive and significant effect on employee performance of PT Agranet Multicitra Siberkom (Detikcom).

Keywords: Emotional intelligence, competence, financial compensation, employee performance

\section{PENDAHULUAN}

Di dalam suatu perusahaan, sumber daya manusia memiliki peranan penting karena pencapaian tujuan perusahaan akan ditentukan oleh kinerja sumber daya manusia yang bertugas melakukan perencanaan, pengorganisasian, pelaksanaan dan pengendalian terhadap sumber daya lainnya yang tersedia di dalam perusahaan tersebut. Oleh karena itu, perusahaan perlu senantiasa meningkatkan kinerja karyawannya agar dapat mencapai tujuannya.

PT Agranet Multicitra Siberkom merupakan perusahaaan yang meluncurkan Detikcom di tahun 1998 dan diakuisisi oleh CT Corp sejak tanggal 3 Agustus 2011. Detikcom merupakan sebuah portal web yang berisi berita aktual dan artikel daring di Indonesia. Detikcom merupakan salah satu situs berita terpopuler di Indonesia karena selalu menjadi yang terdepan dalam memberitakan beragam berita baru (breaking news). 
Berdasarkan data yang diperoleh dari PT Agranet Multicitra Siberkom, meskipun persentase karyawan dengan outstanding, exceed dan meet performance mengalami peningkatan di periode 2013-2016, persentase karyawan dengan below performance juga terus mengalami peningkatan di periode tersebut. Meskipun persentase karyawan dengan below performance di periode tersebut hanya berada di kisaran $0 \%-0,53 \%$, perusahaan perlu memperhatikan dan menanggapi fenomena ini untuk mencegah terjadinya peningkatan persentase karyawan yang memiliki below performance di periode selanjutnya. Perusahaan perlu senantiasa berupaya meningkatkan kinerja karyawannya dan meminimalisasi persentase karyawan yang memiliki kinerja di bawah standar. Perusahaan dapat menggunakan berbagai variabel yang signifikan untuk meningkatkan kinerja karyawannya.

Kinerja perusahaan dapat dipengaruhi oleh berbagai faktor. Salah satunya adalah kecerdasan emosional. Goleman (2006:44) mengemukakan bahwa kecerdasan emosional memberi kontribusi sebesar $80 \%$ terhadap kesuksesan seseorang, sedangkan kemampuan intelektual hanya mampu memberi kontribusi sebesar 20\%. Menurut Goleman (2006), hal tersebut terjadi karena seseorang yang cerdas secara emosional akan mampu mengenali dan mengelola emosi diri, memotivasi dirinya, mengenali emosi orang lain dan membina kerja sama yang baik dengan orang lain.

Kinerja perusahaan juga dapat dipengaruhi oleh kompetensi. Hal ini sejalan dengan hasil penelitian Joune (2015) yang membuktikan bahwa kompetensi berpengaruh positif dan signifikan terhadap kinerja karyawan. Menurut Ruky (2003) dalam Sutrisno (2012), kompetensi seorang karyawan akan memungkinkan karyawan tersebut untuk menjalankan perannya dan menghasilkan prestasi kerja yang memuaskan.

Selain kecerdasan emosional dan kompetensi, faktor lain yang dapat mempengaruhi kinerja karyawan adalah kompensasi finansial. Hal ini sejalan dengan hasil penelitian Lenni (2014) yang membuktikan bahwa kompensasi finansial berpengaruh positif dan signifikan terhadap kinerja karyawan. Menurut Luthans (2006:243), pembayaran yang sesuai merupakan salah satu faktor penting yang dapat mempengaruhi kepuasan kerja karyawan. Oleh karena itu, pemberian kompensasi finansial yang sesuai kepada karyawan akan menimbulkan kepuasan kerja di dalam diri karyawan, sehingga mendorong karyawan tersebut untuk meningkatkan kinerjanya.

Berdasarkan latar belakang di atas, perlu dilakukan penelitian untuk menguji dan menganalisis pengaruh kecerdasan emosional, kompetensi dan kompensasi finansial terhadap kinerja karyawan PT Agranet Multicitra Siberkom (Detikcom). Apabila ketiga variabel 
tersebut terbukti berpengaruh secara signifikan terhadap kinerja karyawan, maka perusahaan dapat menggunakannya sebagai alat peningkatan kinerja karyawannya.

\section{TINJAUAN PUSTAKA}

\section{Pengertian Kinerja}

Dalam KBBI yang dikutip Nawawi (2006:63), kinerja diartikan sebagai: (a) sesuatu yang dicapai, (b) prestasi yang diperlihatkan, dan (c) kemampuan kerja. Menurut Mangkunegara (2009:67), kinerja adalah hasil kerja secara kualitas dan kuantitas yang dicapai pegawai atas pelaksanaan tugas sesuai tanggung jawabnya. Sinambela (2016:481) mendefinisikan kinerja sebagai hasil kerja seseorang atau sekelompok orang dalam organisasi baik secara kuantitatif maupun kualitatif, sesuai kewenangan, tugas dan tanggung jawabnya, dalam upaya mencapai tujuan organisasi secara legal, tidak melanggar hukum dan sesuai dengan moral serta etika.

\section{Faktor yang Mempengaruhi Kinerja}

Menurut Mangkunegara (2009:13), kinerja dapat dipengaruhi oleh faktor-faktor berikut.

1. Faktor Kemampuan

Secara psikologis, kemampuan karyawan terdiri dari kemampuan potensi (IQ) dan kemampuan pendidikan. Karyawan yang berkemampuan baik berarti memiliki kemampuan potensi dan pendidikan yang baik. Karyawan tersebut berlatar belakang pendidikan memadai, sehingga dapat menjalankan tugas sesuai tanggung jawabnya.

2. Faktor Motivasi

Faktor ini terbentuk dari sikap karyawan dalam menghadapi kondisi kerja. Karyawan yang bersifat positif terhadap kondisi kerjanya akan menunjukkan motivasi kerja yang tinggi. Sebaliknya, karyawan yang bersifat negatif terhadap situasi kerjanya akan menunjukkan motivasi kerja yang rendah.

\section{Indikator Kinerja}

Mathis dan Jackson (2006:378) mengemukakan bahwa kinerja memiliki lima indikator berikut.

1. Kuantitas, yaitu jumlah unit yang dihasilkan atau aktivitas yang diselesaikan.

2. Kualitas, yaitu meliputi ketaatan atas prosedur, disiplin dan dedikasi, serta pencapaian hasil aktivitas yang ideal. 
3. Ketepatan waktu, yaitu kemampuan untuk menyelesaikan pekerjaan pada waktu yang telah ditetapkan.

4. Kemampuan bekerja sama, yaitu kemampuan untuk bekerja sama dengan orang lain dalam suatu pekerjaan untuk memaksimalisasi daya dan hasil guna.

\section{Pengertian Kecerdasan Emosional}

Agustian (2009) mendefinisikan kecerdasan emosional sebagai kemampuan untuk merasa. Menurut Goleman (2006:45), kecerdasan emosional merupakan kemampuan memotivasi diri sendiri, bertahan menghadapi frustasi, mengendalikan dorongan hati, tidak melebih-lebihkan kesenangan, mengatur suasana hati dan mencegah agar stres tidak melumpuhkan pikiran, serta berempati dan berdo’a.

\section{Aspek-aspek Kecerdasan Emosional}

Menurut Tridhonanto (2009:5), kecerdasan emosional memiliki aspek-aspek berikut.

1. Kecakapan pribadi, yaitu kemampuan mengelola diri sendiri.

2. Kecakapan sosial, yaitu kemampuan menangani hubungan.

3. Keterampilan sosial, yaitu kemampuan menggugah tanggapan yang dikehendaki orang lain.

\section{Faktor yang Mempengaruhi Kecerdasan Emosional}

Goleman (2006:267) menjelaskan bahwa kecerdasan emosional dipengaruhi oleh dua faktor berikut.

1. Lingkungan Keluarga

Kecerdasan emosional dipelajari sejak bayi melalui ekspresi. Peristiwa emosional di masa kecil akan melekat hingga dewasa. Kehidupan emosional yang dipupuk dalam keluarga akan berguna bagi individu di kemudian hari.

2. Lingkungan Non Keluarga

Lingkungan ini meliputi lingkungan masyarakat dan pendidikan. Kecerdasan emosional berkembang sejalan dengan perkembangan fisik dan mental. Pembelajaran ini dilakukan dalam suatu aktivitas seseorang di luar dirinya dengan emosi yang menyertai kondisi orang lain. 


\section{Indikator Kecerdasan Emosional}

Goleman (2006:58) menyatakan bahwa kecerdasan emosional diukur oleh indikator berikut.

1. Kesadaran diri, yaitu kemampuan mengawasi dan mencermati perasaan.

2. Pengaturan diri, yaitu kemampuan menghibur diri, melepas kecemasan, kemurungan, ketersinggungan dan akibat lainnya dari kegagalan pada keterampilan emosi dasar.

3. Motivasi, yaitu kemampuan mengatur emosi dan menjadikannya alat penguasaan diri dan pencapaian tujuan.

4. Mengenali emosi orang lain (empati), yaitu kemampuan menangkap sinyal sosial tersembunyi yang mengisyaratkan kebutuhan dan kehendak orang lain.

5. Keterampilan sosial, yaitu keterampilan mengelola emosi orang lain, memimpin dan mempertahankan hubungan dengan orang lain melalui keterampilan sosial, mengelola hubungan antarpribadi.

\section{Kompetensi}

Kompetensi diartikan sebagai dimensi keahlian atau keunggulan seseorang yang berketerampilan, berpengetahuan dan berperilaku baik (Sutrisno, 2012:202). Spencer dan Spencer dalam Palan (2007:84) mengemukakan bahwa kompetensi merujuk pada ciri perilaku yang merefleksikan motif, konsep diri, karakter, nilai, pengetahuan dan/atau keahlian yang dibawa seseorang yang berkinerja unggul di tempat kerja.

Kompetensi adalah suatu kemampuan untuk melaksanakan pekerjaan dengan dilandasi keterampilan dan pengetahuan serta sikap kerja sesuai dengan tuntutan (Wibowo, 2011:324). Menurut Spencer dan Spencer dalam Moeheriono (2012:5), kompetensi dapat didefinisikan sebagai karakteristik seseorang terkait efektivitas kinerjanya atau yang memiliki hubungan kausal dengan kriteria acuan, efektivitas serta kinerja prima di tempat kerja.

\section{Faktor yang Mempengaruhi Kompetensi}

Michael (2000) dalam Wibowo (2011:339) kompetensi dipengaruhi oleh: (1) keyakinan dan nilai-nilai, (2) keterampilan, (3) pengalaman, (4) karakteristik kepribadian, (5) motivasi, (6) isu emosional, (7) kemampuan intelektual, dan (8) budaya organisasi.

\section{Indikator Kompetensi}

Menurut Spencer dan Spencer (1993) dalam Sutrisno (2012:206), terdapat lima karakteristik kompetensi yang dapat digunakan sebagai indikatornya, yaitu sebagai berikut. 
1. Motif, yaitu dasar seseorang untuk berpikir secara konsisten dan bertindak.

2. Sifat, yaitu watak yang mendorong untuk berperilaku atau merespon sesuatu.

3. Konsep diri, yaitu sikap dan nilai yang dimiliki seseorang.

4. Pengetahuan, yaitu informasi yang dimiliki seseorang di bidang tertentu.

5. Keterampilan, yaitu kemampuan melaksanakan tugas tertentu, baik secara fisik maupun mental.

\section{Pengertian Kompensasi}

Kompensasi merupakan suatu biaya yang dikeluarkan perusahaan agar memperoleh imbalan berupa prestasi kerja karyawan (Sofyandi, 2008:159). Menurut Panggabean (2000) dalam Sutrisno (2012:181), kompensasi adalah setiap penghargaan yang diberikan organisasi kepada karyawannya sebagai balas jasa atas konstribusi mereka. Simamora (2014:442) mendefinisikan kompensasi sebagai imbalan finansial, jasa dan tunjangan yang diterima karyawan terkait hubungan kepegawaiannya. Menurut Simamora (2014:442), kompensasi merupakan apa yang diterima karyawan sebagai balasan atas kontribusinya kepada organisasi.

\section{Jenis-Jenis Kompensasi}

Simamora (2014:442) membedakan kompensasi menjadi dua jenis, yaitu kompensasi finansial dan non finansial.

1. Kompensasi Finansial

Kompensasi finansial adalah kompensasi yang secara langsung berupa uang, seperti gaji, upah, bonus, dan tunjangan finansial lainnya (Kadarisman, 2012:88). Menurut Simamora (2014:442), kompensasi finansial dapat dibagi menjadi dua macam, yaitu sebagai berikut.

a) Kompensasi Langsung

Kompensasi finansial langsung terdiri dari bayaran dalam bentuk gaji, upah dan insentif.

b) Kompensasi Tidak Langsung

Kompensasi finansial tidak langsung (tunjangan) merupakan semua imbalan finansial yang tidak tercakup dalam kompensasi langsung, yaitu meliputi program perlindungan (asuransi kesehatan, jiwa dan tanaga kerja serta pensiun), bayaran di luar jam kerja (liburan, hari besar, cuti tahunan dan cuti hamil) dan fasilitas (kendaraan, ruang kantor dan tempat parkir). 
2. Kompensasi Non Finansial

Kompensasi non finansial merupakan kompensasi berupa kepuasan yang diperoleh seseorang dari pekerjaannya atau dari lingkungan psikologis dan/atau fisik dimana orang itu bekerja. Kompensasi terkait pekerjaan meliputi tugas yang menarik, tantangan, tanggung jawab, pengakuan dan rasa pencapaian. Sementara itu, kompensasi terkait lingkungan pekerjaan meliputi kebijakan yang sehat, supervisi yang kompeten, kerabat kerja yang menyenangkan dan lingkungan kerja yang nyaman (Simamora, 2014:442).

\section{Fungsi dan Tujuan Pemberian Kompensasi}

Menurut Samsudin (2010:188), pemberian kompensasi memiliki fungsi sebagai berikut.

1. Mengalokasikan sumber daya manusia secara efisien.

2. Menggunakan sumber daya manusia secara lebih efisien dan efektif

3. Mendorong stabilitas organisasi dan pertumbuhan ekonomi

Menurut Notoadmodjo (1992) dalam Sutrisno (2012:188), pemberian kompensasi memiliki tujuan sebagai berikut.

1. Menghargai Prestasi Kerja

Pemberian kompensasi yang memadai merupakan wujud penghargaan perusahaan terhadap prestasi kerja karyawan yang akan mendorong karyawan tersebut untuk berperilaku dan berkinerja sesuai keinginan perusahaan, misalnya berproduktivitas tinggi.

2. Menjamin Keadilan

Sistem kompensasi yang baik akan menjamin terjadinya keadilan di antara karyawan dalam organisasi karena setiap karyawan akan memperoleh kompensasi yang sesuai dengan tugas, fungsi, jabatan dan prestasi kerjanya.

3. Mempertahankan Karyawan

Dengan adanya sistem kompensasi yang baik, para karyawan akan lebih gigih dalam bekerja pada perusahaan itu. Hal ini akan mencegah keluarnya karyawan dari perusahaan untuk mencari pekerjaan yang lebih menguntungkan.

4. Memperoleh Karyawan yang Bermutu

Sistem kompensasi yang baik akan menarik lebih banyak calon karyawan, sehingga memberikan lebih banyak peluang bagi perusahaan untuk memilih karyawan yang terbaik. 
5. Pengendalian Biaya

Sistem kompensasi yang baik akan mengurangi intensitas penyelenggaraan rekrutmen oleh perusahaan karena sistem tersebut akan mencegah karyawan untuk keluar dari pekerjaan dalam rangka mencari pekerjaan yang lebih menguntungkan.

6. Memenuhi Peraturan

Sistem kompensasi yang baik merupakan tuntutan dari pemerintah. Suatu perusahaan yang baik dituntut untuk memiliki sistem administrasi kompensasi yang baik pula.

\section{Faktor yang Mempengaruhi Pemberian Kompensasi}

Ardana, dkk. (2012:153) menjelaskan bahwa faktor-faktor yang mempengaruhi kompensasi terdiri dari: (1) penawaran dan permintaan tenaga kerja, (2) kemampuan dan kesediaan perusahaan, (3) serikat buruh atau organisasi karyawan, (4) produktivitas kerja karyawan, (5) pemerintahan melalui UU dan Keppres, (6) biaya hidup, (7) jabatan karyawan, (8) pendidikan dan pengalaman kerja, (9) kondisi perekonomian nasional, serta (10) jenis dan sifat pekerjaan.

\section{Indikator Kompensasi Finansial}

Menurut Simamora (2014:445), kompensasi finansial dapat diukur dengan indikator berikut ini.

1. Gaji, yaitu balas jasa perusahaan atas kinerja karyawannya yang umumnya diberikan di akhir atau awal bulan.

2. Insentif, yaitu tambahan kompensasi di luar gaji/upah yang diberikan untuk memotivasi karyawan agar berkinerja lebih baik. Insentif disesuaikan berdasarkan produktivitas, penjualan dan keuntungan, misalnya berupa komisi dan bonus.

3. Tunjangan, yaitu tambahan pendapatan di luar gaji yang diterima oleh karyawan sebagai bantuan., misalnya asuransi kesehatan dan jiwa, liburan yang ditanggung perusahaan dan program pensiun.

4. Fasilitas, yaitu sarana yang memudahkan pelaksanaan kerja, misalnya fasilitas mobil perusahaan.

\section{Keterkaitan antara Kecerdasan Emosional dan Kinerja}

Goleman (2006:44) mengemukakan bahwa kecerdasan emosional memberi kontribusi sebesar $80 \%$ terhadap kesuksesan seseorang, sedangkan kemampuan intelektual hanya mampu memberi kontribusi sebesar 20\%. Menurut Goleman (2006), hal tersebut terjadi 
karena seseorang yang berketerampilan dalam kecerdasan emosional akan mampu mengenali dan mengelola emosi dirinya, memotivasi diri sendiri, mengenali emosi orang lain, serta membina hubungan kerja sama.

Menurut Goleman (2006), kecerdasan emosional dapat membuat seseorang mampu bertahan menghadapi frustasi, mengendalikan dorongan hati, tidak melebih-lebihkan kesenangan, mengatur suasana hati, dan mencegah agar stres tidak melumpuhkan pikiran. Kemampuan yang dibangun kecerdasan emosional tersebut akan membantu karyawan dalam meminimalisasi hambatan yang dihadapinya terkait pelaksanaan kerja, sehingga karyawan tersebut dapat menyelesaikan pekerjaannya dengan baik dan meningkatkan kinerjanya. Hal ini sejalan dengan hasil penelitian oleh Marga (2016) dan Yakub, dkk. (2015) yang menunjukkan bahwa kecerdasan emosional berpengaruh positif dan signifikan terhadap kinerja karyawan.

$\mathrm{H}_{1}$ : Kecerdasan emosional berpengaruh positif dan signifikan terhadap kinerja karyawan PT Agranet Multicitra Siberkom (Detikcom).

\section{Keterkaitan antara Kompetensi dan Kinerja}

McClelland dalam Sutrisno (2012:209) mengemukakan bahwa kompetensi non akademik, kemampuan inovasi, management skill, dan kecepatan mempelajari jaringan kerja akan mampu memprediksi prestasi yang dicapai seseorang dalam pekerjaannya. Hal tersebut terjadi karena kompetensi memadai yang dimiliki oleh seorang karyawan akan membantu karyawan tersebut untuk memahami pekerjaannya serta standar dan target perusahaan. Prestasi kerja berupa pencapaian standar dan target perusahaan tersebut menunjukkan bahwa karyawan berhasil memberikan kinerja yang baik bagi perusahaan. Dalam penelitiannya, Joune (2015) dan Budiman, dkk. (2016) juga membuktikan bahwa kompetensi berpengaruh positif dan signifikan terhadap kinerja karyawan.

$\mathrm{H}_{2}$ : Kompetensi berpengaruh positif dan signifikan terhadap kinerja karyawan PT Agranet Multicitra Siberkom (Detikcom).

\section{Keterkaitan antara Kompensasi Finansial dan Kinerja}

Hasil penelitian oleh Lenni (2014) dan Sari, dkk. (2016) menunjukkan bahwa kompensasi finansial berpengaruh positif dan signifikan terhadap kinerja karyawan. Luthans (2006:243) menyatakan bahwa pembayaran yang sesuai merupakan salah satu faktor penting yang dapat mempengaruhi kepuasan kerja karyawan. Oleh karena itu, pemberian kompensasi finansial yang sesuai akan menimbulkan kepuasan kerja di dalam diri karyawan, sehingga 
memotivasi karyawan tersebut untuk melaksanakan pekerjaannya dengan baik dan sesuai standar serta target perusahaan.

$\mathrm{H}_{3}$ : Kompensasi finansial berpengaruh positif dan signifikan terhadap kinerja karyawan PT Agranet Multicitra Siberkom (Detikcom).

\section{Kerangka Analisis}

Kerangka analisis penelitian ini disajikan pada gambar berikut.

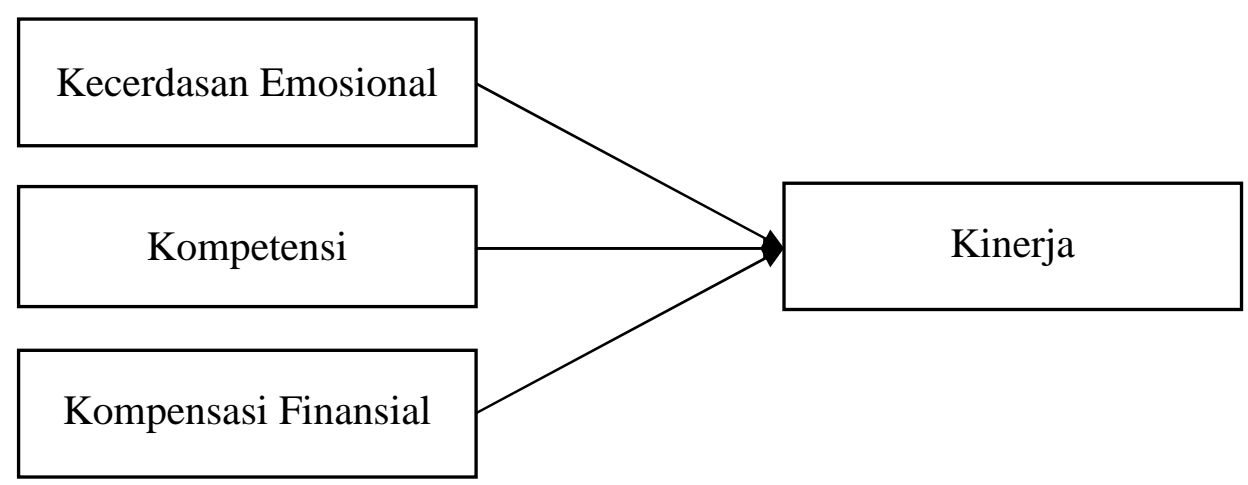

\section{Gambar 1. Kerangka Analisis}

\section{METODE PENELITIAN}

\section{Sumber dan Jenis Data}

Data penelitian ini merupakan data cross section. Berdasarkan sumbernya, data dapat dikategorikan sebagai data primer karena berasal dari hasil penyebaran kuesioner kepada responden.

\section{Populasi dan Sampel}

Populasi penelitian ini adalah seluruh karyawan tetap PT Agranet Multicitra Siberkom (Detikcom) yang sudah bekerja minimal selama satu tahun terhitung hingga Februari 2017. Berdasarkan kriteria tersebut, populasi penelitian terdiri dari 396 karyawan. Dengan menggunakan rumus Slovin, sampel penelitian ini berjumlah 80 responden.

\section{Definisi Operasional Variabel}

Berikut ini adalah definisi operasional atas variabel penelitian. 
Tabel 1. Definisi Operasional Variabel

\begin{tabular}{|c|c|c|}
\hline Variabel & Definisi Operasional & Indikator \\
\hline Kinerja & $\begin{array}{l}\text { Hasil kerja seseorang dalam } \\
\text { melaksanakan tugasnya }\end{array}$ & $\begin{array}{l}\text { 1. Kuantitas } \\
\text { 2. Kualitas } \\
\text { 3. Ketepatan waktu } \\
\text { 4. Kemampuan bekerja sama } \\
\text { Sumber: Mathis dan Jackson } \\
\text { (2006:378) }\end{array}$ \\
\hline $\begin{array}{l}\text { Kecerdasan } \\
\text { Emosional }\end{array}$ & $\begin{array}{l}\text { Kemampuan untuk memahami dan } \\
\text { mengelola emosi }\end{array}$ & $\begin{array}{l}\text { 1. Kesadaran diri } \\
\text { 2. Pengaturan diri } \\
\text { 3. Motivasi } \\
\text { 4. Mengenali emosi orang lain } \\
\text { (empati) } \\
\text { 5. Keterampilan social } \\
\text { Sumber: Goleman }(2006: 58)\end{array}$ \\
\hline Kompetensi & $\begin{array}{l}\text { Penguasaan tugas, keterampilan dan } \\
\text { sikap yang dapat menunjang suatu } \\
\text { pekerjaan }\end{array}$ & $\begin{array}{l}\text { 1. Motif } \\
\text { 2. Sifat } \\
\text { 3. Konsep diri } \\
\text { 4. Pengetahuan } \\
\text { 5. Keterampilan } \\
\text { Sumber: Spencer dan Spencer } \\
\qquad \text { (1993) dalam } \\
\quad \text { Sutrisno (2012:206) }\end{array}$ \\
\hline $\begin{array}{l}\text { Kompensasi } \\
\text { Finansial }\end{array}$ & $\begin{array}{l}\text { Penghargaan untuk karyawan dalam } \\
\text { bentuk uang dan tunjungan }\end{array}$ & $\begin{array}{l}\text { 1. Gaji } \\
\text { 2. Insentif } \\
\text { 3. Tunjangan } \\
\text { 4. Fasilitas } \\
\quad \text { Sumber: Simamora (2014:445) }\end{array}$ \\
\hline
\end{tabular}

\section{Metode Analisis}

Regresi linear berganda digunakan untuk menganalisis pengaruh kecerdasan emosional, kompetensi dan kompensasi finansial terhadap kinerja karyawan PT Agranet Multicitra Siberkom (Detikcom).

\section{HASIL PENELITIAN DAN PEMBAHASAN}

\section{Hasil Penelitian}

Uji instrumen dilakukan dengan uji validitas dan reliabilitas. Berdasarkan hasil uji validitas, setiap pernyataan kuesioner bersifat valid karena memiliki $\mathbf{r}_{\text {hitung }}$ yang lebih besar daripada $r_{\text {tabel. }}$. Sementara itu, hasil uji reliabilitas menunjukkan bahwa semua variabel bersifat reliabel karena memiliki nilai Cronbach Alpha yang lebih besar daripada 0,6. 
Uji asumsi klasik yang dilakukan dalam penelitian ini terdiri dari uji normalitas, multikolinearitas, heteroskedastisitas dan autokorelasi. Hasil uji normalitas dengan menggunakan grafik p-plot menunjukkan bahwa data yang digunakan dalam penelitian ini menyebar mengikuti dan mendekati garis diagonal, sehingga data tersebut terdistribusi normal. Sementara itu, hasil uji multikolinearitas menunjukkan bahwa tidak terjadi multikolinearitas dalam model regresi ini karena setiap variabel independen memiliki nilai tolerance yang lebih besar daripada 0,1 dan nilai VIF yang lebih kecil daripada 10.

Hasil uji heterokedastisitas dengan menggunakan uji Glesjer menunjukkan bahwa tidak terjadi heterokedastisitas dalam model regresi ini karena semua variabel independen memiliki signifikansi yang lebih besar daripada 0,05. Sementara itu, hasil uji autokorelasi menunjukkan bahwa tidak terjadi autokorelasi dalam model regresi ini karena memenuhi kriteria dU < DW < 4-dU. Berdasarkan hasil seluruh uji asumsi klasik tersebut, model regresi yang digunakan dalam penelitian ini terbukti dapat memenuhi semua persyaratan yang dibutuhkan.

Setelah memenuhi seluruh syarat uji instrumen dan asumsi klasik, dilakukan uji regresi linear berganda untuk menganalisis pengaruh dari setiap variabel independen terhadap variabel dependen. Berikut ini disajikan persamaan dari hasil uji regresi linear berganda yang telah dilakukan.

$$
Y=12,857+0,351 X_{1}+0,220 X_{2}+0,173 X_{3}
$$

Keterangan:

$$
\begin{array}{ll}
\mathrm{Y} & =\text { Kinerja karyawan } \\
\mathrm{X}_{1} & =\text { Kecerdasan emosional } \\
\mathrm{X}_{2} & =\text { Kompetensi } \\
\mathrm{X}_{3} & =\text { Kompensasi finansial }
\end{array}
$$

Selain beberapa pengujian yang telah dilakukan di atas, juga dilakukan uji $\mathrm{F}$ dan uji koefisisen determinasi. Hasil uji F menunjukkan bahwa model regresi dalam penelitian ini memiliki nilai $F_{\text {hitung }}$ yang positif dan lebih besar daripada $F_{\text {tabel}}$, sehingga dapat disimpulkan bahwa kecerdasan emosional, kompetensi dan kompensasi finansial secarasimultan berpengaruh positif dan signifikan terhadap kinerja karyawan. Hal tersebut menunjukkan bahwa model yang digunakan dalam penelitian ini bersifat layak. Sementara itu, hasil uji koefisien determinasi menunjukkan bahwa besarnya koefisien determinasi dari model yang digunakan adalah 0,398. Hal tersebut menunjukkan bahwa kecerdasan emosional, kompetensi dan kompensasi finansial memberikan kontribusi sebesar 39,8\% dalam mempengaruhi 
kinerja karyawan, sedangkan 60,2\% sisanya dipengaruhi oleh variabel-variabel lain yang tidak dianalisis dalam penelitian ini.

Hipotesis penelitian diuji dengan menggunakan uji t. Hasil uji t tersebut menunjukkan bahwa setiap variabel independen memiliki nilai t yang positif dengan nilai signifikansi yang lebih kecil daripada $\alpha$ sebesar 0,05, sehingga dapat disimpulkan bahwa kecerdasan emosional, kompetensi dan kompensasi finansial secara parsial berpengaruh positif dan signifikan terhadap kinerja karyawan PT Agranet Multicitra Siberkom (Detikcom).

\section{Pembahasan}

\section{Pengaruh Kecerdasan Emosional terhadap Kinerja Karyawan}

Hasil penelitian ini menunjukkan bahwa kecerdasan emosional berpengaruh positif dan signifikan terhadap kinerja karyawan PT Agranet Multicitra Siberkom (Detikcom). Artinya, semakin tinggi tingkat kecerdasan emosional seorang karyawan, maka semakin baik kinerja karyawan tersebut. Hal ini sejalan dengan hasil penelitian yang dilakukan oleh Marga (2016) dan Yakub, dkk. (2015).

Fitriastuti (2013) menyatakan bahwa karyawan yang mempunyai kecerdasan emosional tinggi akan bekerja lebih baik sesuai standar organisasi, sehingga mampu mencapai kinerja yang lebih baik. Carmeli (2003) menyatakan bahwa karyawan dengan tingkat kecerdasan yang tinggi dapat mengelola emosi mereka dalam hal mempertahankan keadaan mental yang positif yang dapat menyebabkan peningkatan kinerja.

Goleman (2006:44) mengemukakan bahwa kecerdasan emosional memberi kontribusi sebesar $80 \%$ terhadap kesuksesan seseorang, sedangkan kemampuan intelektual hanya mampu memberi kontribusi sebesar 20\%. Menurut Goleman (2006), hal tersebut terjadi karena seseorang yang berketerampilan dalam kecerdasan emosional akan mampu mengenali dan mengelola emosi diri, memotivasi diri sendiri, mengenali emosi orang lain, dan membina hubungan kerja sama. Hal tersebut mencerminkan bahwa seseorang yang berketerampilan dalam kecerdasan emosional akan mampu mengatasi berbagai hambatan yang dihadapinya dalam mencapai tujuannya melalui berbagai upaya pengelolaan hubungan interpersonal dan intrapersonal, sehingga orang tersebut pada akhirnya akan mampu mencapai tujuannya tersebut.

Menurut Goleman (2006), kecerdasan emosional dapat membuat seseorang mampu bertahan menghadapi frustasi, mengendalikan dorongan hati, tidak melebih-lebihkan kesenangan, mengatur suasana hati, dan mencegah agar stres tidak melumpuhkan pikiran. 
Kemampuan yang dibangun kecerdasan emosional tersebut akan membantu karyawan untuk meminimalisasi hambatan yang dihadapinya dalam menyelesaikan pekerjaannya.

Goleman (2006) juga menjelaskan bahwa kecerdasan emosional akan membangun keterampilan sosial, yaitu keterampilan mengelola emosi orang lain dan mempertahankan hubungan dengan orang lain. Keterampilan tersebut akan sangat berguna dalam membantu karyawan untuk menjalin hubungan yang baik dengan rekan kerjanya, sehingga dapat menciptakan teamwork yang solid dan lingkungan kerja yang harmonis. Akibatnya, efektivitas pelaksanaan pekerjaan karyawan akan mengalami peningkatan, sehingga kinerja karyawan tersebut juga akan mengalami peningkatan.

\section{Pengaruh Kompetensi terhadap Kinerja Karyawan}

Hasil penelitian ini menunjukkan bahwa kompetensi berpengaruh positif dan signifikan terhadap kinerja karyawan PT Agranet Multicitra Siberkom (Detikcom). Artinya, semakin tinggi kompetensi karyawan, maka semakin baik kinerja yang dihasilkannya. Hal ini sejalan dengan hasil penelitian yang dilakukan oleh Joune (2015) dan Budiman, dkk. (2016). Ruky (2003) dalam Sutrisno (2012) mengemukakan bahwa kompetensi yang dimiliki karyawan akan memungkinkan karyawan tersebut untuk melaksanakan perannya dan menghasilkan prestasi kerja yang memuaskan.

Kompetensi adalah suatu kemampuan untuk melaksanakan pekerjaan dengan dilandasi keterampilan dan pengetahuan serta sikap kerja sesuai dengan tuntutan (Wibowo, 2011:324). Berdasarkan definisi tersebut, karyawan dengan kompetensi tinggi berarti memiliki keterampilan dan pengetahuan yang tinggi pula serta sikap kerja yang baik untuk melaksanakan pekerjaannya dengan baik. Akibatnya, karyawan tersebut akan mampu mencapai hasil yang baik dari pekerjaan yang dilaksanakannya tersebut.

McClelland dalam Sutrisno (2012:209) mengemukakan bahwa kompetensi non akademik, kemampuan inovasi, management skill, dan kecepatan mempelajari jaringan kerja akan mampu memprediksi prestasi yang dicapai seseorang dalam pekerjaannya. Hal tersebut terjadi karena kompetensi memadai yang dimiliki oleh seorang karyawan akan membantu karyawan tersebut untuk memahami pekerjaannya serta standar dan target perusahaan. Prestasi kerja berupa pencapaian standar dan target perusahaan tersebut menunjukkan bahwa karyawan berhasil memberikan kinerja yang baik bagi perusahaan. 


\section{Pengaruh Kompensasi Finansial terhadap Kinerja Karyawan}

Hasil penelitian ini menunjukkan bahwa kompensasi finansial berpengaruh positif dan signifikan terhadap kinerja karyawan PT Agranet Multicitra Siberkom (Detikcom). Artinya, semakin baik dan sesuai kompensasi finansial yang diberikan perusahaan kepada karyawannya, maka semakin baik pula kinerja yang dihasilkan oleh karyawan tersebut. Hal ini sejalan dengan hasil penelitian yang dilakukan oleh Lenni (2014) dan Sari, dkk. (2016).

Kompensasi merupakan balas jasa yang diterima karyawan atas pekerjaan yang dilakukannya yang dipergunakan olehnya untuk memenuhi kebutuhannya dan keluarganya. Besarnya kompensasi yang diterima karyawan akan mencerminkan status, pengakuan dan tingkat pemenuhan kebutuhan karyawan tersebut bersama keluarganya. Semakin besar kompensasi yang diterima karyawan, maka semakin tinggi jabatannya, semakin baik statusnya dan semakin banyak pemenuhan kebutuhan yang dinikmatinya. Akibatnya, kepuasan kerjanya juga semakin baik (Hasibuan, 2008:117). Kepuasan kerja yang dirasakan oleh karyawan tersebut akan mendorongnya untuk senantiasa berupaya melaksanakan pekerjaannya dengan baik dalam rangka memenuhi standar dan target perusahaan.

Notoadmodjo (1992) dalam Sutrisno (2012:188) mengemukakan bahwa pemberian kompensasi yang memadai bertujuan untuk memberi penghargaan terhadap prestasi kerja karyawan. Pemberian kompensasi tersebut akan mendorong karyawan untuk berperilaku dan berkinerja sesuai kehendak perusahaan. Penerapan sistem kompensasi yang baik dan adil di suatu perusahaan juga akan membuat karyawan menjadi lebih gigih dalam melaksanakan pekerjaannya.

\section{KESIMPULAN DAN SARAN}

\section{Kesimpulan}

Berdasarkan hasil penelitian, kecerdasan emosional, kompetensi dan kompensasi finansial secara parsial berpengaruh positif dan signifikan terhadap kinerja karyawan PT Agranet Multicitra Siberkom (Detikcom).

\section{Saran}

Berdasarkan hasil penelitian, berikut ini merupakan saran untuk meningkatkan kinerja karyawan.

1. Perusahaan diharapkan dapat senantiasa memperhatikan kecerdasan emosional karyawannya dengan menyelenggarakan workshop dan seminar bertema kecerdasan emosional secara rutin. 
2. Perusahaan diharapkan dapat senantiasa berupaya meningkatkan kompetensi karyawannya dengan menyelenggarakan diklat terkait posisi yang didudukinya.

3. Perusahaan diharapkan dapat meninjau kembali sistem kompensasi finansial yang diterapkannya.

4. Perusahaan diharapkan dapat senantiasa menerapkan sistem kompensasi finansial yang adil dan memadai bagi karyawannya.

\section{DAFTAR PUSTAKA}

Agustian, A.G. 2009. Rahasia Sukses Membangun Kecerdasan Emosi dan Spiritual ESQ: Emotional Spiritual Quotient. Arga Publishing. Jakarta.

Ardana, I.K., N.W. Mujiati dan I.W.M. Utama. 2012. Manajemen Sumber Daya Manusia. Edisi Pertama. Graha Ilmu. Yogyakarta.

Budiman, N.P., I.S. Saerang dan G.M. Sendow. 2016. Pengaruh Kompetensi, Motivasi dan Disiplin Kerja terhadap Kinerja Karyawan: Studi pada PT Hasjrat Abadi Tendean Manado. Jurnal EMBA. 4(4): 321-332.

Carmeli, A. 2003. The Relationship Between Emotional Intelligence and Work Attitudes, Behavior and Outcomes. Journal of Manajerial Psychology. 18(8): 788-813.

Fitriastuti, T. 2013. Pengaruh Kecerdasan Emosional, Komitmen Organisasional dan Organizational Citizenship Behavior terhadap Kinera Karyawan. Jurnal Dinamika Manajemen. 4(2): 103-114.

Goleman, D. 2005. Emotional Intelligence: Why It Can Matter More than IQ. Bantam Book. New York. Terjemahan T. Hermaya. 2006. Kecerdasan Emosional: Mengapa EI Lebih Penting daripada IQ. Gramedia Pustaka Utama. Jakarta.

Hasibuan, M.S.P. 2008. Manajemen Sumber Daya Manusia. Edisi Revisi. Bumi Aksara. Jakarta.

Joune, R.R.C. 2015. Pengaruh Kompetensi dan Stres Kerja terhadap Kinerja Pegawai pada Dinas Pendidikan Nasional Provinsi Sulut. Jurnal EMBA. 3(3): 1243-1253.

Kadarisman, M, 2012. Manajemen Pengembangan Sumber Daya Manusia. Edisi Pertama. Rajawali Pers. Jakarta.

Lenni, N. 2014. Pengaruh Kompensasi Finansial dan Non Finansial terhadap Kinerja Karyawan PT Pertamina EP Bunyu Field Kabupaten Bulungan. E-Jurnal Ilmu Administrasi Bisnis. 2(4): 513-526.

Luthans, F. 2005. Organizational Behavior. $10^{\text {th }}$ Ed. McGraw-Hill. New York. Terjemahan V.A. Yuwono, S. Purwanti, A. Prabawati, dan W. Rosari. 2006. Perilaku Organisasi. Edisi 10. Andi. Yogyakarta. 
Mangkunegara, A.A.A.P. 2009. Manajemen Sumber Daya Manusia Perusahaan. Remaja Rosdakarya. Bandung.

Marga, K.Y. 2016. Pengaruh Pelatihan, Kecerdasan Emosional dan Budaya Organisasi terhadap Kinerja Karyawan pada PT Pelayaran Tempuran Emas Surabaya. E-Jurnal Manajemen Kinerja. 2(1): 22-36.

Mathis, R.L. dan J.H. Jackson. 2003. Human Resource Management. Tenth Edition. SouthWestern. Mason. Terjemahan D. Angelica. 2006. Manajemen Sumber Daya Manusia. Edisi 10. Salemba Empat. Jakarta.

Moeheriono. 2012. Pengukuran Kinerja Berbasis Kompetensi. Edisi Revisi. Raja Grafindo Persada. Jakarta.

Nawawi, H. 2006. Manajemen Sumber Daya Manusia untuk Bisnis yang Kompetitif. Gadjah Mada University Press. Yogyakarta.

Palan, R. 2003. Competency Management. Percetakan Suma. Kuala Lumpur. Terjemahan O.M. Jalal. Manajemen Kompetensi. 2007. PPM. Jakarta.

Ruky, A.S. 2003. Kualitas Sumber Daya Manusia. Gramedia Pustaka Utama. Jakarta.

Samsudin, S. 2010. Manajemen Sumber Daya Manusia. Pustaka Setia. Bandung.

Sari, G.A.W.P., L.G.L. Kusuma dan N.P.E. Mahadewi. 2016. Pengaruh Kompensasi Finansial Langsung, Kompensasi Finansial Tidak Langsung dan Kompensasi Non Finansial terhadap Kinerja Karyawan pada PT Telkom Manado. Jurnal IPTA. 4(2): 82-87.

Simamora, H. 2014. Manajemen Sumber Daya Manusia. Edisi 3. STIE YKPN. Yogyakarta.

Sinambela, L.P. 2016. Manajemen Sumber Daya Manusia. Bumi Aksara. Jakarta.

Sofyandi, H. 2008. Manajemen Sumber Daya Manusia. Edisi 1. Graha Ilmu. Yogyakarta.

Sutrisno, E. 2012. Manajemen Sumber Daya Manusia. Edisi 1. Kencana Prenadamedia Group. Jakarta.

Tridhonanto, A. 2009. Melejitkan Kecerdasan Emosi (EQ) Buah Hati. Elex Media Komputindo. Jakarta.

Wibowo. 2011. Manajemen Kinerja. Edisi Kedua. Rajawali Pers. Jakarta.

Yakub, S., R. Gunawan dan J. Halim. 2015. Pengaruh Kemampuan Komunikasi dan Kecerdasan Emosional terhadap Kinerja Karyawan pada PT Perkebunan Nusantara I (Persero) Aceh. Jurnal SAINTIKOM. 14(3): 160-170. 